\title{
Erfaring av pasjonshistorien til salig liv
}

\author{
Sjelesorg for dødsdømte i Danmarks \\ og Noriges Kirke-Ritual
}

\author{
Professor, dr.theol. em. \\ Bernt Torvild Oftestad, MF vitenskapelig hoyskole for \\ teologi, religion og samfunn
}

Abstract: In the Twin Realms of Denmark-Norway the king was also responsible for the religious life of his subjects. Kirkeritualet [The Church Ritual] of 1685 was an expression of the king's care for his subjects. It included even guidelines for the priest's spiritual care for those condemned to death. A "pious repentance", rooted in the mystical tradition, became an important aspect of Lutheran Christianity following the Reformation. A reckoning with sin, conversion, and the interiorization of faith, following the Order of Salvation, was the path to a new and eternal life. It was by interiorizing the biblical narrative - for those condemned to death, the Passion of Christ - that one took part in such a sanctifying process. The spiritual advisor made the biblical text affective and present, using rhetorical means, in order to transform the heart. After uniting with Christ in the Eucharist the condemned could go to his death on the path to eternal life.

Key Words: death sentence - mystical tradition - the Church Ritual rhetoric - Art of Dying - Order of Salvation

28. April 1772 ble Johann Friedrich Struensee (1737-1772) henrettet i København. En kort tid hadde han på grunn av sitt nære forhold til dronningen hatt anledning til å endre stats- og samfunnsliv i pakt med Opplysningens ideer. Avsatt ved et kupp og senere dømt for høyforræderi ("crimen majestatis") var Struensees skjebne gitt. Veien til skafottet var lagt. ${ }^{1}$ I følge kirkelig lov og instruksjon, gitt med Kirkeritualet av 1685, ble Balthasar Münter (1735-93), prest ved den tyske kirken i København, satt til å å være hans sjelesørger. ${ }^{2}$ Kirkeritualet gav en bred veiledning for prestens pastorale tjeneste. ${ }^{3} \mathrm{Med}$

1. Kong Christian den Femtes Dansk Lov (København: Gad 1929), 6. Bok, 4. Kapittel, 1. art.; Jens Glebe-Møller, Struensees vej til skafottet. Fornuft og åbenbaring $i$ Opplysningstiden (København: Museum Tusculanums Forlag 2007), 9.

2. Ibid. 44f. Merethe Roos, Enlightened Preaching. Balthasar Münter's Authorship 1772-1793 (Leiden/Boston: Brill 2013).

3. Danmarks og Norgis Kirke-Ritual (Udvalget for Konvent for Kirke og Theologi 1985); http://www.lutherdansk.dk/web-kirke-ritualet\%201685/web-kirke-ritualet $\% 201685 /$ index.htm (besøkt 04.02.19). 
til tjenesten hørte sjelesørgerisk ansvar - for fanger og forbrytere og blant dem de dødsdømte. ${ }^{4}$ En rekke forbrytelser kunne bli straffet med døden. ${ }^{5} \AA$ A lede den dødsdømte frem til rett syndserkjennelse, bot, omvendelse og frelsende tro på Kristus var et overordnet mål. På sin måte, betinget av sin tid, fulgte Münter opp ritualets sjelesørgeriske formål. Etter henrettelsen publiserte han en beretning om sine sjelesørgeriske samtaler med Struensee og hans egen fremstilling av hvordan han hadde gjennomlevd en utvikling frem til omvendelse. ${ }^{6}$

Kirkeritualets veiledning for sjelesorg overfor den dødsdømte er det sentrale tema i denne fremstilling. I veiledningen er en karakteristisk bruk av Skriften knyttet sammen med en "religiøs psykologi", som tegner en sjelesørgerisk profil. Den kan avdekkes og karakteriseres fremfor alt teologihistorisk. I sin sjelesorg følger Münter Kirkeritualets sjelesørgeriske mål. Samtidig ledes han av ideer som er annerledes enn tenkesettet i ritualet. Det gis en viss kontinuitet, men fremfor alt en klar nyorientering. Her traderes og endres.

\section{Historiske forutsetninger og bakgrunn}

Den dødsdømte skal nå saligheten etter henrettelsen. I Kirkeritualet er det sjelesorgens formål. Forutsetningen er at vedkommende har tilegnet seg troen ved personlig erfaring. Også hos Münter er Struensees erfaring avgjørende. I følge Struensees egen fremstilling skjedde en endring i hans sinn ("Gesinnungen") i forhold til religionen. Religiøs erfaring har sitt sted i psyken, men den har også et innhold, som tilegnes av "jeget", gjerne forstått som den søkende individuelle personlighet. Dette er et paradigme som har sine teologiske røtter i senantikken (Augustin), og som har levd videre helt inn i vår tid. ${ }^{7}$

4. Kirkeritualet (1985), VI. Capitel, IV. art., som var konsetrert om hjelp til de 1 de døende. Gyda Hesla, Sjelesorg overfor kvinner i kirkeordinansen og kirkeritualet (Det teologiske menighetsfakultet, Oslo, upublisert essay-kirkehistorie 2002).

5. Dødsstraff rammet den som drev med blasfemi og trolldom. Det samme gjaldt opprør og landsforræderi, mord, fosterdrap, voldtekt, seksualitet i "strid med naturen" og blodskam. Dansk Lov 6. bok, Om Misgierninger; Tyge Krogh, Oplysningstiden og det magiske. Henrettelser og korporlige straffe i 1700-tallets forste halvdel (København: Samleren 2000), 99-272.

6. Balthasar Münter, Bekehrungsgeschichte des vormaligen Grafen und Königl. Dänischen Geheimen Cabinetsministers Joh. Fried. Struensee nebst desselben eigenhändiger Nachricht von der Art, wie er zur Aenderung seiner Gesinnungen über die Religion gekommen ist (Kopenhagen: Bayrhoffer 1772).

7. William James, The Varieties of Religious Experience (Cambridge/London: Harvard University Press 1902/1985); Charles Taylor, Sources of The Self. The Making of 
Tenkesettet preget også sjelesorgstradisjonen fra senmiddelalderen, ikke minst skrifter om sjelesorg for de døende, som fikk en oppblomstring på denne tiden. Tekster om Ars moriendi ("kunsten å dø") ble nærmest en egen genre. ${ }^{8}$ Man la vekt på at menneskets åndelig tilstand i dødsøyeblikket var avgjørende for dets evige skjebne, om det gikk til evig pine eller evig salighet. En rekke spørsmål ble stilt til den døende: Holdt vedkommende fast ved troen, angret den døende sine synder, søkte han Guds tilgivelse og barmhjertighet, ville man gjøre opp for synd mot andre mennesker og forlate dem som hadde gjort en urett. Hadde man vilje til å gjøre bot for synden og sette Kristi død mellom seg og dommen. Mennesket skulle ledes til rett søken etter Gud, dvs. søke Kristus for ved troen på ham å kunne unnfly fortapelsen og nå frem til saligheten. Mønsteret gjenfinnes i Kirkeritualet (Kirkeritualet 1985, 90f). Den sjelesørgeriske kommunikasjon skjedde ikke ved ord alene. Den syke skulle ha krusifiks og helgenbilder for sitt øye. Senmiddelalderens kommunikasjon skjedde ikke minst ved bildet. Det skjulte blir synlig ved ytre, synlige midler. Særlig viktig ble bilder av Kristi korsfestelse. ${ }^{9}$

Ars moriendi-tradisjonen ble ført videre inn i reformasjonen, men på nye premisser. ${ }^{10}$ I 1519 utgav Martin Luther (1483-1546) Eyn Sermon von der Bereytung zum Sterben. ${ }^{11}$ Luther ville formidle en oppfatning

the Modern Identity (Cambridge: Cambridge University Press 1989); Charles Taylor, Varieties of Religion Today (Cambridge/London: Harvard University Press 2002).

8. Behovet for åndelig hjelp ved dødsleiet var stort under senmiddelalderen. Prestene greide ikke å ta seg av alle. Legfolk måtte hjelpe til. For å instruere dem (og prester), ble det laget veiledninger for slik sjelesorg. Den mest kjente var forfattet av den franske teologen Jean Gerson (1363-1429). Han utgav i 1408 det treleddede verket: Opusculum tripartitum de preceptis decalogi, de confessione et de arte moriendi. Tredje delen ble utgitt separat under tittelen: Ars moriendi. Den kom også ut på svensk: Markus Hagberg, Jean Gersons Ars moriendi. Om konsten att dø (Värnamo: Skara stiftshistoriska sällskaps skriftserie: 45 2009), 35-68. Svensk oversettelse av Ars Moriendi ved Per-Axel Wiktorsson, ibid. 91-24; Allen Verhey, The Christian Art of Dying. Learning from Jesus (Grand Rapids: B. Eerdmanns Publishing 2011), 79-83; Tarald Rasmussen red, $\AA$ minnes de døde. Døden og de døde $i$ Norge etter reformasjonen (Oslo: Cappelen Damm 2019), 29-35.

9. Stina Fallberg Sundmark, “Om konsten att dö på rätt sätt”, Hagberg (2009), 3567; David Freedberg, The Power of Images. Studies in the History and the Theory of Respons (Chicago/London: The University of Chicago Press 1989), 168-175; Mitchell B. Merback, The Thief, the Cross and the Wheel. Pain and Spectacle of Punishment in Medieval and Renaissance Europe (London: Reaction books Ltd 1999), 41-68.

10. Volker Leppin, "Preparing for Death. From the Late Medieval ars moriendi to the Lutheran Funeral Sermon", Preparing for Death, Remembering the Dead, red. Tarald Rasmussen \& Jon Øygarden (Göttingen: Vandenhoeck \& Ruprecht 2015), 9-21.

11. "Eyn Sermon von der Bereytung zum Sterben", Martin Luther. Studienausgabe I, red. Hans-Ulrich Delius (Berlin: Evangelische Verlagsanstalt 1979), 232-239; 
av døden i samsvar med sin lære om rettferdiggjørelse ved tro. Ved troen på Kristus alene kunne det døende mennesket ha visshet om sin frelse. ${ }^{12}$ I sin "Sermon" konsentrerte Luther seg om å formidling av den rette åndelig kunnskap: Døden er et farvel til denne verden, men også en ny fødsel som gir del i salighetens glede.

Veien til saligheten åpnes ved nådens midler: dåpen, nattverden, skriftemålet. Luther viste også til bildets betydning, ikke konkrete ting som krusifiks og helgenbilder, men til exempla fra Det gamle testamente, der Israels fiender nedkjempes av Gud (Dom 7,16-22 og Jes 9,3f.). Det samme skjedde da Kristus seiret over døden, synden og Satan og vant oss frelsen, liv og salighet. Nådemidlenes/sakramentene skal gi oss del i den frelsende kristusvirkelighet, som de er tegnene på. For Luther er sakramentene "Guds synlige ord". Gud taler ved dem om trøsten i Kristus, som må mottas i tro. Den blir illustrert og formidlet også ved historiske eksempler, som er "bilder" som styrker troen. ${ }^{13}$

Kirkeritualets "metode" og formål med sjelesorgen overfor dødsdømte er å utlegge pasjonshistorien i Skriften slik at den virker tro og frelse i den som er på vei til henrettelsen. "Ars moriendi"-tradisjonen føres videre på flere måter. Sjelesorgen skal lede til syndserkjennelse, bot og tro. Vekten legges på den åndelige tilstand ved dødsøyeblikket. Presten følger den dødsdømte til øksen faller. Hva så med den billedlige kommunikasjon? I en evangelisk-luthersk utlegningstradisjon, som Kirkeritualet inngår i, er utgangspunktet at Skriften brukes i pakt med det lutherske "Skriften alene". Det fortsetter at Skriften "utlegger seg selv". Og Skriften er "offentlig", slik at dens saklige innhold er klart for enhver ut fra teksten ("ytre klarhet") og for hjertet ved Åndens gjerning til tro ("indre klarhet"). Skriftens egentlige innhold og formål er proklamasjonen av evangeliets løfte som mottas i (fiducial) tro. ${ }^{14}$ I Kirkeritualet møter vi en utvidet bruk av Skriften.

Jenny Marie Kvisler Lillevold, Kunsten å dø. En tolkning av Martin Luthers 'Eyn Sermon von der Bereytung zum Sterben' sett i lys av den senmiddelalderske Ars moriendi-tradisjonen (Oslo Universitet: upublisert ph.d.-avhandling 2013).

12. Også andre reformatorer som Johannes Oecolampadius (1482-1531) og Johannes Bugenhagen (1485-1558) skrev veiledninger for de døende. Austra Reinis, Reforming the Art of Dying. The ars moriendi in the German Reformation (1519-1528) (Burlington: Ashgate 2007), 1-45.

13. Luther (1979), 239. Luther benytter her en retorisk figur for å overbevise. Birgit Stolz, Martin Luthers Rhetorik des Herzens (Tübingen: Mohr Siebeck 2000) 72-74, 42-61.

14. Friedrich Beisser, Claritas Scripturae bei Martin Luther (Göttingen: Vandenhoeck \& Ruprecht 1966); Jun Matsuura, "Duo Cherubin adversis vultibus. Zur Herausbildung und texthermeneutishen Bedeutung des Grundsatzes Scriptura sui ipius interpres", Reformatorische Theologie und Autoritäten, red. Volkert Leppin (Tübingen: Mohr Siebeck 2015), 41-173. 
Skriftteksten skal påvirke mennesket, slik at det tilegner seg troen ved en erfaring som utløses nettopp i møtet med teksten. Det vil si historien om Kristi pasjon, som skal påvirke og utløse troserfaring.

Her står vi overfor en fromhetstradisjon som begynner i middelalderen. I fransiskanske miljøer tok man pasjonen som utgangspunkt for from meditasjon og kontemplasjon. Traktater, som inneholdt pasjonsberetningen, ble utarbeidet. En rik flora av pasjonstekster ble utgitt. Etter hvert kom større fremstillinger av Vita Christi. Kristi lidelse fremstilles i all sin gru - detaljert og brutalt. Stadig insisteres det på den affekt dette utløser hos dem som "ser" pasjonen - altså gjennom teksten. Denne pasjonskontemplasjon ut fra tekst korrelerer metodisk med billedlig (retorisk formatert) skriftutlegning. Luther var skeptisk til billedlig bruk av Skriften til å forankre teologisk lære, det hindret likevel ikke at han brukte retorikkens midler i formidling og opplæring. Humanister som Erasmus av Rotterdam (1466-1536) og Phillip Melanchthon (1497-1560) nyttet derimot retorikken i selve skriftutlegningen. Det gav grunnlag for en såkalt affektiv teologi. For Melanchthon rommet ikke Skriften bare et budskap/lære som mottas i troens tillit, men den utløste også handling, emosjonell og eksistensiell erfaring. ${ }^{15}$ Det antropologisk-pykiske korrelatet til den affektive skriftutlegning var hjertet ("cor"), der både affekt og vilje har sitt sted. ${ }^{16}$ Etter hvert trengte en retorisk tenkemåte, ja metode sterkere inn i luthersk-reformatorisk teologi. ${ }^{17}$ Dette blir reflektert også 100 år senere i Kirkeritualets tekstbruk?

15. Siegfried Wiedenhofer, Formalstrukturen humanistischer und reformatorischer Theologie bei Pillip Melanchthton 1-2 (Frankfurt am Main/München: Peter Lang 1976), 66-78, 333-336.

16. "The emotive functions of the sensitive soul resided in the heart." Katharine Park, "The organic soul", The Cambridge History of Renaissance Philosophy, red. Charles B. Schmitt (Cambridge: Cambridge University Press 1988), 464-484, 469. Dette var en arv fra Augustins personalitetsfilosofi. A. Maxsein, Philosophia cordis. Das Wesen der Personalität bei Augustin (Salzburg: Otto Müller 1966). Bruk av "hjerte" hos Luther: Stolz (2000), 49-53.

17. Martin Schian,"Die Homiletik des Andreas Hyperius, ihre wissenschaftliche Bedeutung und ihr praktischer Wert", Zeitschrift für praktische Theologie (1896), 289-324; ibid. (1897), 27-49; Bernt Torvild Oftestad, "Lehre, die das Herz bewegt", Archiv für Reformationsgeschichte 80 (1989), 125-153. 


\section{Pønitense - veien gjennom bot til evig liv}

Kongen som hadde vedtatt Kirkeritualet, truet med å straffe dem som ikke rettet seg etter det. ${ }^{18}$ Geistligheten (kirken og skolen) skulle opplære folket i den rette tro. Også i strafferettspleien var dette oppdrag integrert. Sjelesørgerisk omsorg for dødsdømte viser nettopp det. Ikke bare undersåttenes tro og liv i denne verden, også deres evige frelse i den kommende lå kongen på hjerte. Danmark-Norge, som var en evangelisk-luthersk konfesjonsstat, hadde en særegen rettskultur, et viktig trekk var integrasjonen av stat og religion. ${ }^{19}$

Prestens oppgave i følge Kirkeritualet er å føre "Fanger og Misdædere", som lider for sine ugjerninger, inn i boten eller pønitensen, som er den rette forberedelse til å motta Kristi legemes og blods sakrament. Et viktig trekk ved etterreformatorisk fromhetsliv var kravet til de troende om å leve i pønitense, dvs. i anger og sorg over synden, for på den måten å kunne begynne å leve et nytt og hellig liv. ${ }^{20}$ Pønitensen inngikk i en psyko-religiøs dannelsesprosess gjennom forskjellige stadier, en "ordo salutis". ${ }^{21}$ At den enkelte og folket skulle leve i bot og bønn, inngikk også i kongens religionsprogram. I 1686 ble det forordnet en faste-, bots- og bededag. ${ }^{22}$ I Kirkeritualet er det anført en salme fra Hans Thomissøns danske salmebok fra 1569 som blir betegnet som en pønitensesalme. Den henspiller på kong Davids synd og bot (Kirkeritualet 57). ${ }^{23}$ Botsfromhet ble fra 1600-tallets begynnelse for alvor integrert i luthersk lære og tro. ${ }^{24}$

18. “Kongens Forord," Kirkeritualet (1985), 7.

19. 1600-tallets konfesjonsstat tok ansvar for undersåttenes tro og moral, ja evige salighet. På offentlige bygninger og på kirkeinventaret i Danmark-Norge og hertugdømmene finnes valgspråket: "Regna firmat pietas” ofte forkortet til R.F.P. Chr. Gorm Tortzen, "Regna firmat pietas", Den Store Danske, http://denstoredanske.dk/ index.php?sideId=149675 (besøkt 04.02.19). Ralf Michaels, "Legal Culture”, Forthcoming in Oxford Handbook of European Private Law, red. Jürgen Basedow, Klaus J. Hopt \& Reinhard Zimmermann (Oxford: Oxford University Press 2009), 1-7.

20. Det var ved phillipismen og under ortodoksien at kravet om pønitense ble et avgjørende trekk ved fromhetslivet i Danmark-Norge. Kim Gørlitz \& Ole Hoffmann, Synden i hjertet-djevelen i kroppen (København: Akademisk Forlag 1987), 97-127.

21. Ibid. 128-136. "The Sacrament of Penance," http://www.newadvent.org/cathen/11618c.htm, (sist besøkt 04.03.19).

22. Ved reformasjonen ble bots- og bededagene avskaffet. Men de kom etter hvert tilbake. Ved kgl. forordning av 1686 ble de mange bededagene slått sammen til én, som skulle holdes 4. søndag etter påske.

23. Pønitensesalmene har en bestemt rubrikk i Den danske Psalmebog/met mange Christelige Psalmer/Ordentlig tilsammenset/formeret oc forbedret. Aff Hans Thomissøn. Kiøbenhaffn, 172-189.

24. Den viktigste formidler var Johann Arndt (1555-1621). Christian Braw, Bücher im Staube. Die Theologie Johann Arndts in ihrem Verhältnis zur Mystik (Leiden: E. J. 
Forberedelsen til å motta sakramentet begynner derfor med å formane fangen til sannhetens erkjennelse. Å gi Satan rom slik at man motstår sannheten og taler løgn, er en forherdelse som vil vekke desto større vrede og hevn fra Gud. Derfor gjelder det åpent å erkjenne sine forseelser "og give Gud ære" (Ibid. 85, 5-15). ${ }^{25}$ Fangen har forbrutt seg mot den verdslige loven, og det er det han skal straffes for. Det bør utløse anger og "Ruelse" i hjerte og sinn over de syndige lovbrudd. Presten skal så ut fra Guds ord holde frem alle synders "Vederstyggelighed," og særlig den synd han nå må lide for: tyveri, mord eller andre ugjerninger. Fangen må gå i seg selv og innse hvor stor synden er, særlig i Guds øyne. Men veien inn i pønitensen går lenger enn det. Hele livet må gjennomtenkes om man skal komme frem til en rett og sann syndserkjennelse, også slikt som ikke bryter med straffeloven. Hvordan har det vært med drukkenskap, usedelighet, gjerrighet og hat, ulydighet mot foreldre og andre foresatte? Brudd på helligdagsbudet trekkes også inn og forsømmelse av Guds ord (dvs. kirkens gudstjenesteliv). Syndserkjennelsen vekkes når lyset fra Guds bud faller over livet. Både den første og annen tavles bud har fangen forbrutt seg mot (Ibid. 85,30-86, 5).

Den åndelige prosessen skal ikke stanse ved angeren og boten. Sjelesørgeren skal føre den botferdige frem til tro på frelsen i Kristus. Satan må ikke forføre ham til å tro at pønitensen har vært forgjeves, at det ikke gis noen frelse for dem som har forskutt Guds nåde, at han har tatt sin ånd fra dem og oppgitt dem. For om vi har syndet, er Gud trofast, han som har svoret at han ikke har "Lyst til nogen Synders Død, men at hand maa omvende sig og leve" (Esek 33,11; dessuten Rom 5,20).

Sjelesørgeren gir så en åndelig tolkning av livet til de som straffes. De er underlagt Guds forsyn og hans pedagogiske ledelse av livet. De har erfart "Plager, Trængsel, Fængsel og Døden selv". Siden Gud ikke har kunnet lede dem til sann omvendelse og tro ved sin godhet, har han måttet gripe til tunge prøvelser for at de skulle komme til sine synders erkjennelse. Sjelesørgeren nytter et klassisk retorisk virkemiddel for at den straffedømte skal kunne tilegne seg innsikt i Guds handling med menneskene. Han viser til eksempler fra den bibelske historie

Brill 1985); Martin Brecht, "Das Aufkommen der neuen Frömmigkeitsbewegung in Deutschland. Johann Arndt und das Wahre Christentum", Geschichte des Pietismus 1 (Göttingen: Vandenhoeck \& Ruprecht 1993), 130-150; Erik A. Nielsen, Thomas Kingo. Barok, enevalde, kristendom. Billed-sprog II (København: Gyldendal 2010), 328-330.

25. Det henspilles på Akan i Josvas bok, som tok av det gods som var bannlyst. Herrens vrede kom over Israel. Og Josva sa til Akan: "Min sønn. Gi Herren Israels Gud ære og pris. Fortell meg hva du har gjort og skjul ikke noe for meg." Det gjorde Akan, men han ble likevel henrettet. Josv 7,19-26. 
som kong Manasse av Juda, som svek Herren, ble straffet, omvendte seg og ble vist nåde (2 Krøn 33,10-13). Også Akan og røveren på korset blir trukket frem, den sistnevnte er selve kroneksemplet på den botferdiges frelse (Jos 7,20; Luk 23,42). Den straffedømte kan lære av og fremfor alt identifisere seg med disse eksemplariske personer fra den bibelske historien.

Det historiske eksempel blir ytterligere konkretisert og får enda større læringskraft når fokus blir flyttet til det konkrete fengsel som den dømte er innsatt i. I Apg 16 fortelles det om et fengsel som her tillegges eksemplarisk betydning: På sin andre misjonsreise ble Paulus og Silas arrestert. Mens de satt fengslet i byen Filippi, sang de lovsanger og bad til Gud. Dette er et forbilde også for dagens fanger. De bør være i bønn og lovsynge Gud. Om de ikke har tatt imot troen, bør de lære av fangevokteren i Filippi, og slik som han ta imot evangeliet i tro. De kan være forvisset om at Gud er nådig, selv overfor dem som har gjort de groveste synder. De kan ha tillit til at Gud vil gi den botferdige det svar han gav røveren på korset.: "I dag skal du være med meg i paradis" (Ibid. 86,5-87,15).

Den luthersk-ortodokse pønitenseteologi legger føringene i Kirkeritualet. Sjelesørgeren står derfor overfor den oppgave å overtale den dødsdømte til å tilegne seg den åndelige erfaring som pønitensen består i, for den er en nødvendig forberedelse og forutsetning for å motta og nyte sakramentet. ${ }^{26}$ Psyke og sakrament blir slik knyttet sammen. Dermed får bruk av et retorisk utlegningsmønster som er rettet nettopp mot psyken, en helt avgjørende teologisk tyngde. ${ }^{27}$ Det formidler kunnskap ("docere"), blant annet ved hjelp av illustrasjoner eller "exempla" fra "historia"/" res gesta" som kan overbevise. ${ }^{28} \mathrm{Og}$ den dømte blir på den måten også mentalt beveget ("movere"), slik at den affekt fremkalles, som er pønitensen rette mentale uttrykk. ${ }^{29}$ I pasjonsberetningens "historia" gis det dessuten ytterligere "exem-

26. M. Kraus,"Pathos", Historische Wörterbuch der Rhetorik, 6, red. Gert Ueding (Tübingen: Walter de Gruyter 2003), 689-717.

27. Om retorikk i luthersk teologi under senreformasjonen. Oftestad (1998) 125153.

28. Quintillian om exemplum: "Potentissimum autem est inter ea quae sunt huius generis, quod proprie vocamus exemplum, id est rei gestae aut ut gestae utilis ad persuandum id quod intenderis commemoratio." " The most important of proofs of this class is that which is most properly styled example, that is to say the adducing of some past action real or assumed which may serve to persuade the audience of the truth of the point which we are trying to make." Quintilian, "Intitutio Oratoria”, II Book IV-VI, The Loeb Classical Library, red. G. P. Goold (London: William Heinemann 1977), XI, 6-7. $274 f$.

29. "Officia oratoris", https://de.wikipedia.org/wiki/Officia_oratoris (sist besøkt 05.03.19). 
pla". De vil åpne for den botferdiges "conformitas" med den lidende Kristus i troens erfaring, som også er sakramentalt forankret i nytelsen av Kristi legeme og blod i nattverden.

\section{Historia, exemplum, conformitas}

Når dagen for henrettelsen er kommet, skal presten, i hvis sokn den skal finne sted, være "betimeligen hos den Fangne, een eller to Timer” på forhånd. Det gjelder å minne den dømte om den åndelige erkjennelsen han allerede har tilegnet seg ved bekjennelse, sorg og anger over synden og tro på det frelsende evangelium. Men nå skjer det en aksentforskyvning i veiledningen. Den dødsdømte formanes til "Bestandighed" $\mathrm{i}$ troen når han nå skal gå den tunge veien som ender med eksekvering av den (døds)straff som Gud har gitt ham å lide for sine synders skyld. Nå kan han også glede seg over at denne dagen vil bli hans siste "Strids-Dag", og at hans elendighet snart vil få sin ende. Det gjelder å holde fast ved troen på at veien går mot evig salighet og et udødelig liv hos Gud i himmelen. Han oppfordres til å be om kraft til å holde ut denne siste prøven, slik at han kan bli en "Sejervinder" (Ibid. 87, 26-88,16). Presten må støtte ham ved bønn, lesning og sang. Egnet i så måte er strofene fra litaniet: "O du Guds Lam." Den dødsdømte skal lære om pasjonen, og læren skal overbevise og bevege. Og til sist skal den også skape glede/"delectare”.

Kirkeritualet tar frem skriftord som viser at innlevelse i pasjonen vil kunne gi glede. Dette blir demonstrert ved tolkningen av ordet "tørst" i Joh 19,29-30: “(...) for at Skriften skulle bli oppfylt sa han: 'Jeg tørster.' Det stod et kar der med vinedikk. De fylte en svamp med den, satte svampen på en isopstilk og holdt den opp til munnen hans. Da Jesus hadde fătt vineddiken sa han: 'Det er fullbrakt!'” Eksemplet motiverer presten til å lede den dødsdømte ut av sorgen og angsten. Om han merker "Frygt eller Banghed" hos "Synderen", som er på vei mot retterstedet, skal han la ham få vin. For Gud har selv befalt (Ordspr 31,6f.) å gi de bedrøvede vin å drikke, slik at de kan glemme sin elendighet og ikke tenke på sin jammer og ulykke. I dette ligger også mulighet for at den dødsdømte kan få en dypere erkjennelse.

Den dødsdømtes angst stilles ved å drikke naturlig vin. Denne handling blir transcendert ved å aktualisere den vin han nettopp drakk, da han mottok det høyverdige sakrament. Vinen i sakramentet er Kristi blod utøst på korset. Pasjonens Kristus er virkelig, sakramentalt nærværende, men han er også potensielt nærværende ved all tørst og all vin, siden Kristus på korset tørstet og ble gitt vin å 
drikke. Vinen som gis den dødsdømte, blir et tegn på Kristi tørst. Om han (fortsatt) tørster, skal den tørst han nå har, være tørsten etter å nyte den salighet som Jesus vant for oss på korset. For om kort tid vil han få denne tørsten slukket i himmelen. Der skal han i fryd og usigelig glede drikke av de "søde Vellysters Strømme", som er "den livsalige Engledrikk". I overflod skal han nyte denne drikk sammen med Guds hellige og utvalgte. Det naturlige, det sakramentale og det historiske tegn peker gjensidig på hverandre, men de peker også ut over seg selv til en annen og transcendent eskatologisk virkelighet (Ibid. 88,17-35).

Når "Synderen" er på vei til retterstedet, skal presten følge den dødsdømte, og han skal holde frem for ham, hvor vanskelig veien var for Frelseren, han som gikk til sin død blant illgjerningsmenn for våre synder. Ved hvert trinn den dødsdømte tar, kommer han nærmere friheten fra synd, bånd og fengsel. Vanskelige reiser har han gjort før i denne verden. De brakte ham i nød og fare. Snart kommer han til et sted, der han kan si som David: "Min sjel fall til ro, min sjel har Herren fridd fra døden, mitt øye fra gråt og min fot fra fall. Jeg skal vandre for Herren i de levendes land" (Sal 116,7-9). Ved å ta utgangspunkt $\mathrm{i}$ den botferdiges vandring kan sjelesørgeren gjøre den alminnelige vandringen i verden til et eksempel som aktualiseres soteriologisk som vandringen mot saligheten. På den videre vei mot henrettelsen skal sjelesørgeren holde frem, alle bibelsteder (loca cardinalia) som forteller om Guds overveldende miskunn overfor den botferdige (Ibid. 89,1-31). Hele veien frem til retterstedet tar sjelesørgeren hånd om den dømte og gir trøst ved hjelp av Guds ord. Han skal også lede ham til en offentlig bekjennelse av sin tro og til å tilgi alle som har gjort ham ondt. Han skal ikke bære hat til noen i sitt hjerte, heller ikke mot den øvrighet som rettelig straffer ham. Den dødsdømte spørres så om han er fullkomment beredt og villig til å død for de synder han har gjort. Boten skal bringe den dødsdømte til frivillig å ta straffen på seg og innse at den er rett og rettferdig. En full og hel erkjennelse av synd betyr også erkjennelse av at den dødsstraff som rammer ham, er rett. I dette fullbyrdes pønitensen. Og nå kan presten avløse ham i kraft av den myndighet Gud har gitt ham til å bruke nøklemakten. Nå er den dømte helt og fullt rede til å møte sin Gud (Ibid. 90,25-91,20).

Presten skal bli hos forbryteren mens han gjøres ferdig til "Executionen". Før den finner sted, vil den dødsdømte kunne bli bundet på hender og føtter. Igjen tar Kirkeritualet utgangspunkt i konkret liv for ved hjelp av pasjonens eksempel å åpne for en dypere åndelig erkjennelse: Repene skal minne den dødsdømte om "hvad Baand CHristus Guds Søn maatte lide for hans skyld”. Om en liten stund 
kan den dømte vise seg som en "ret Samson" og slite over dødens band, fordi Kristus har gjort dødens makt til intet. Det vises til 1. Kor 15,55, 57. Presten blir hos den dødsdømte helt til henrettelsen er fullbyrdet. Hele tiden skal han lese og be for ham. Om han utsettes for tortur, skal presten rope til ham og oppfordre ham til stadig å be: "Herre Jesus forbarme deg over meg" (Ibid. 92,5-93,15).

På vei mot retterstedet gjenfinner den dødsdømte forbryter sitt egentlige liv ved identifikasjon med Kristus i hans pasjon, slik evangeliene beretter denne histori". I den er de exempla, som peker mot og motiverer likedannelsen med Kristus i hans lidelse. Den dødsdømte innlemmes i den åndelig virkelighet som gir conformitas med Kristus. Slik blir den sakramentale enhet med Kristus bevisstgjort for den troende i og med hans egen vei til retterstedet og Kristi pasjonshistorie blir knyttet sammen. For i hans egen menneskelige historie gis analogier til den høyere bibelske og kristologiske historien. Når det enkelte menneskeliv blir innlemmet ved bot og tro i den kristologisk bestemte historien, føres det troende mennesket til saligheten. Der får menneskets angst og lidelse sin slutt for å kunne nyte en "himmelsk drikk", erfare frihet og salighet.

I Kirkeritualet står bibelutleggelsen i sjelesorgens tjeneste. Men sjelesørgeren viser ikke bare til tekster som kan ha betydning for den dødsdømte, denne trekkes også inn i teksten ved hjelp av retoriske grep som knytter tekst og liv sammen. Det vises til den dødsdømtes liv før han ble dømt, og fremfor alt til det liv han nå erfarer under den siste tid før dommen fullbyrdes. Tekstutleggelsen skal gjør mer enn å klarlegge skriftinnholdet for å omforme det ved abstrakte lærebegreper slik at det blir betydningsfull kunnskap for den som hører. Tilhører/leser skal ved (retorisk) utlegning blir forent med den virkelighet som teksten gjør nærværende ved skriftord som har konkret innhold og referanse. Her føres anliggender fra senmiddelalderens mystiske imitatio-fromhet videre. Også den var båret av bildet av den korsfestede. Kristi pasjon ble objektet for en kontemplasjon som ledet inn i lidelsesfellesskapet med Kristus. Dette kunne skje ved meditasjon over bibeltekstene, med enda større kraft ved bildet av den lidende Kristus som vehikel for åndelig fordypning. I Kirkeritualet beror foreningen med Kristus ikke primært på den troendes åndelige empati, men den har sin forutsetning i boten ved skriftmålet og sakramentalt ved den konkrete handling å spise og drikke brød og vin.

At Skriftens bruk står i sentrum for sjelesorgen i en kirke som er luthersk-ortodoks, er selvsagt. Det man møter i Kirkeritualet, er likevel en annen skriftbruk enn den typisk reformatoriske med vekten lagt på det klare budskap formidlet ut fra tekstens likefremme (filologisk/grammatikalske) mening. Men ikke desto mindre også hos 
Luther - særlig den unge Luther - er den mystiske tradisjon levende og da med billedlig bruk av bibelteksten. ${ }^{30}$ Med Johann Arndt (15551621), hvis mystiske teologi fant veien inn i det lutherske rom ut over på 1600-tallet, ble skriftbruken innfattet i den troendes etterfølgelse av Kristus (imitatio Christi). Han så Kristi liv, slik det er fremstilt i Skriften, som et eksempel for oss, som skal forme våre liv, slik at vi virkeliggjør den kjærlighet og ydmykhet som Kristus har vist oss. Kristus er vårt livs bok. Beretningen om hans pasjon blir den sentrale teksten for oss. Av boken følger at Kristus både er frelser og et forbilde til etterfølgelse. Uten kristusetterfølgelse gis ingen tro, ingen salighet og enhet med Gud.

Den skriftbruk vi møter i Kirkeritualet finner man igjen - nærmest paradigmatisk - hos salmedikteren, Thomas Kingo (1634-1703), som bidro til den kirkelige fornyelsen som kom ved slutten av 1600-tallet. I 1699 ble Dend Forordnede Ny Kirke-Psalme-Bog autorisert av kongen for bruk i alle kirker i Danmark-Norge. I Kingos langfredagssalme: "BRyder frem I hule Sukke" gis en dramatisk fremstilling av Kristi pasjon med allusjoner bl.a. til protevangeliet i 1 Mos 3,15. ${ }^{31}$ Her er også en skriftbruk som vi gjenkjenner fra Kirkeritualet. I en strofe i v.14 heter det: "Paa hans Kors Pilatus skriver Jøde-Konges Titel op (...)." Salmedikterens poeng er at denne "historia" (Joh 19,19) skal innskrives i våre hjerter, slik at Jesus også blir min konge. Hans ære "min Salighed skal være". Pilatus' skrevne betegnelse: "Jøde-Konge" blir en "historia" som ved en troens "conformitas" blir billedlig "skrevet" på mitt hjerte. Slik overskrides den historiske avstand mellom Golgata den gang og våre liv i dag. At innskriften skjer på "hjertet", er ingen tilfeldighet. Vekten på hjertet som religiøst sentrum i mennesket har sin bakgrunn hos Augustin. Humanismen fører tanken videre inn i nytiden ved sin affektive teologi. I humanismen finner man så igjen den syntese av et praktisk-affektivt formål og bruk av retorikkens midler. Det gir skriftteksten en fornyende kraft for, ja inn i den troendes hjerte.

30. Martin Luther, "De libertate/Christiana/Von der Freiheit eines Christenmenschen, 1520", Martin Luther. Studienausgabe 2, red. Hans-Ulrich Delius, (Berlin: Evangelische Verlagsantalt 1982), 260-309. Luther anfører forholdet mellom brud-brudgom som et bilde på den troendes forhold til Kristus. Ibid. 275-277.

31. Salmen har 29 vers. Bare vers 15: "Skriv deg, Jesus, på mitt hjerte” er brukt i dag i Den danske salmebog (2003), 208 og Norsk salmebok (2013), 339. Salmen er skrevet i 1680-årene og ble først publisert i Kingos salmebokutkast fra 1689. Senere ble den tatt inn i den autoriserte salmeboken av 1699 (som kom til å hete: Kingos salmebok). Anders Malling, Dansk salmehistorie IV (København: J. H. Schultz forlag 1964), 357-362; http://adl.dk/solr_documents/kingo04val-workid112444\#kbOSD-0=page: 1 (sist besøkt 12.10.19). 


\section{Kirkeritualet tradert under opplysningen - et prominent eksempel}

Presten Balthasar Münter, som ble satt til å være sjelesørger for Struensee, representerte en gren av Opplysningen (neologien), som ønsket å forene fornuft og kristen åpenbaringstro. ${ }^{32}$ Struensees livssyn var derimot formet av den radikale franske Opplysning, den var både antiklerikal og antireligiøs, basert på et materialistisk-mekanistisk menneskesyn. Gjennom samtalene med Münter ble Struensee ledet til en kristen omvendelse. Etter Struensees' død publiserte Münter sine opptegnelser fra disse samtalene. Alt i samtiden ble det reist tvil om sannhetsgehalten i hans fremstilling. ${ }^{33}$ Münter hadde et apologetisk formål da han gav offentligheten innsyn i Struensees religiøse utvikling. I en tid preget av kvasse angrep på kristendommen trengte de troende et vitnesbyrd som viste at det gikk en vei fra kristendomskritikk til tro, fra religionsfornektende rasjonalisme til religiøs omvendelse. Og dette kunne skje gjennom en sjelesørgerisk prosess. Men uansett sannhetsgehalt, Münters opptegnelser gir innblikk i hvordan man fulgte opp Kirkeritualets mønster for sjelesorgen overfor dødsdømte 100 år etter.

Münter hadde som mål å "omvende" Struensee. Han settes til å lese pasjonsprekener. Og han viser sin botferdighet, og Münter trøster ham med ord fra Rom 8. Kort før øksen faller, holder Münter frem Kirkeritualets tre spørsmål: Om han angrer sine synder mot Gud og mennesker. Om han forlater seg på Kristi forsoning for å finne nåde hos Gud. Og til sist om han tar avskjed med denne verden uten fiendtlige følelser overfor andre mennesker. På alle tre spørsmål svarer Struensee ja. Münter følger altså Kirkeritualets sjelesørgeriske intensjon. Men det er først kort tid før henrettelsen at Kirkeritualets veiledning slår direkte igjennom. Det viser en tydelig avstand mellom Kirkeritualets sjelesørgeriske metode og opplysningsteologien til Münter.

Kirkeritualet lar pasjonshistorien i Skriften bli en "historia" som beveger hjertet affektivt, slik at troens frimodighet og (eskatologiske) glede vokser frem i den dødsdømte. Boten er begynnelsen til en slik

32. Om neologien: Karl Aner, Theologie der Lessingzeit (Hildesheim: Georg Olms Verlagsbuchandlung 1929/1964); Walter Sparn, "Vernünftiges Christentum. Über die geschichtliche Aufgabe der theologischen Aufkläurung im 18. Jahrhundert in Deutschland", Wissenschaft im Zeitalter der Aufkärung, red. Rudolf Vierhaus (Göttingen: Vandenhoeck \& Ruprecht 1985), 18-57. I Münters tekst fra 1772 vises det gjerne til den tyske teologen Johann Joachim Spalding (1714-1804), som var en kjent neolog i samtiden. Dominique Bourel, "Spalding" Theologische Realenzyklopädie, XXXI (Berlin/New York: Walter de Gruyter, 2000), 607-610.

33. Glebe-Møller (2007), 103. Kirkeritualet (1985), $91 f$. 
utvikling. Münter har på sin side en apologetisk-intellektuell innfallsvinkel. Han opplyser og veileder for å overbevise. Det gir sjelesorgen et filosofisk-teologisk preambel.

Münters bakgrunn var den tidlige tyske Opplysning, hvis ledende skikkelse var filosofen Christian Wolff (1679-1754), som utviklet en metafysikk som skulle begrunne harmoni mellom fornuft og åpenbaring. ${ }^{34}$ Åpenbaringssannhetene var suprarationale, men ikke i strid med fornuften. Den (fornuftige) metafysikk åpnet veien til Gud. Slik kunne de åpenbarte sannheter forsvares mot evangeliets fiender, mente Wolff. ${ }^{35}$

Hos Struensee utvirker Münter i første omgang en "filosofisk omvendelse". Grunnlaget er Wolffs naturlige teologi. Ledet av fornuftige argumenter må Struensee oppgi den materialistiske tanken om mennesket som en maskin. Det består tvert imot både av legeme og sjel, og sjelen lever videre etter legemets død. Mennesket har samvittighet, som gir grunnlaget for moralen. ${ }^{36}$ Men Struensee må ved bot og tro ledes videre til en kristen omvendelse. Münter veileder ham ved å gi ham å lese et utvalg av samtidens teologisk litteratur, som skal rydde vekk radikal opplysningskritikk av kristendommen. Hvilken rolle spiller Skriften i denne prosessen? Münter nøler med å legge Skriften i Struensees hendene. Når han til sist gjør det, er det Det nye Testamente han setter ham til å lese. Han må være sikker på at Struensee leser bibelteksten på riktig måte. Det krever historisk-kritisk bevissthet. ${ }^{37}$ For Jesu historie er spredt ut over alle fire evangelier, og mangt et sted er ikke riktig oversatt, og adskillige vil være uforståelig for Struensee på grunn datidens seder og skikker. ${ }^{38} \mathrm{Ut}$ fra bibeltekstene overbeviser han Struensee om den kirkelige lære om forsoningen, Kristi to naturer og treenigheten. Forholdet mellom fornuftig opplysning og bibelsk åpenbaringshistorie er imidlertid ikke alltid like lett å komme til rette med.

34. Johannes Hirschberger, Geschichte der Philosophie II (Köln: Komet 1980), 259261; Aner (1929/1964), 4-6, 22ff.; Franklin Kopitzsch, Aufklärung, Absolutismus und Bürgertum in Deutschland (München: Nymphenburger Verlagsbuchandlung 1976), 275-318.

35. Wolff spilte en dominerende rolle i samtidens danske filosofi. Karl Henrik Koch, Dansk oplysningsfilosofi (København: Gyldendal 2000), 21-25.

36. Blant de opplysningsfilosofer som Münter anbefalte for Struensee, var Johann Friedrich Wilhelm Jerusalem (1709-1789). Glebe-Møller (2007), 61-69.

37. I følge Münter hadde Johann Salomo Semler (1725-1791), en av Opplysningens fremste bibelkritikere, som ble utsatt for angrep fra ortodokse teologer, gjort religionen store tjenester. Ibid. 60.

38. Ibid. $80 f$. 


\section{Avslutning og kort utblikk}

$\AA$ lede det dannede opplyste mennesket frem til kristen tro er for Münter et apologetisk opplysningsprosjekt. Og apologetikken består i å forberede tilegnelse av troen ved metafysisk, antropologisk og moralsk erkjennelse. En slik tilnærming hadde vært fremmed for Luther. Men aristotelisk metafysikk ble senere tatt opp i den lutherske ortodoksi. ${ }^{39}$ Også til Kirkeritualet er avstanden formidabel. Der blir mennesket ved hjertets affektfulle tilegnelse satt inn i pasjonshistorien. Hos Münter blir mennesket forberedt ved å tilegne seg en fornuftig metafysisk overbevisning som kan gjøre det rasjonalt mulig å godta åpenbaringsreligionen. Her settes ikke mennesket ved hjertet inn $i$ Skriften, men Skriften gjøres gyldig for mennesket ved rasjonale kriterier for å forstå den rett.

På 1700-tallet var den åndshistoriske konteksten for Kirkeritualet blitt sterkt endret i forholdet til tiden da det ble til. Skriften var ikke lenger den autoritative og avgjørende kilde til en alminnelig tolkning av menneskets liv, død og skjebne i det hinsidige. Det ble en filosofisk og teologisk utfordring å forsvare kristentro og Skrift. Med det fulgte også en frontforkortning av Skriftens bruk betinget av den teologisk-filosofiske forsvarsstrategi. Den affektive tilnærming ble dog ført videre igjennom opplysningstiden og inn i 1800-tallets nyprotestantiske teologi. Sjelesorgens profil ble endret, men den affektive tilnærming ble beholdt, ja etter hvert forsterket innen rammen av den mentalitetshistoriske utvikling. Men det skulle gå lang tid før dødsstraffen ble opplevd som emosjonelt og også ideologisk utålelig.

39. Luther holdt avstand til, ja avviste så vel aristotelisk-skolastisk som occamistisk metafysikk som basis for teologien. "Disputatio Heidelbegae habita", Martin Luther. Lateinisch-Deutsch Studienausgabe I, red. Wilfried Härle (Leipzig: Evangelische Verlagsanstalt 2016), 35-69; "Disputatio contra scholasticam theologicam", Ibid. 19-33; Heiko Augustinus Oberman, Luther. Man between God and the Devil (New Haven: Yale University Press 1989), 120; B.A. Gerrish, Grace and Reason. A Study in the Theology of Luther (Oxford: Claredon Press 1962), 54f.; Walter Sparn, Wiederkehr der Metaphysik. Die ontologische Frage in der lutherischen Theologie des frühen 17. Jahrhunderts (Stuttgart: Calwer Verlag 1976). 